\title{
Behavioral Disinhibition and Reduced Anxiety-like Behaviors in Monoamine Oxidase B-Deficient Mice
}

\author{
Marco Bortolato', ${ }^{1,3}$ Sean C Godar',3, Shieva Davarian', Kevin Chen' and Jean C Shih*,1,2 \\ 'Department of Pharmacology and Pharmaceutical Sciences, School of Pharmacy, University of Southern California, Los Angeles, CA, USA; \\ ${ }^{2}$ Department of Cell and Neurobiology, Keck School of Medicine, University of Southern California, Los Angeles, CA, USA
}

\begin{abstract}
Monoamine oxidase (MAO) B catalyzes the degradation of $\beta$-phenylethylamine (PEA), a trace amine neurotransmitter implicated in mood regulation. Although several studies have shown an association between low MAO B activity in platelets and behavioral disinhibition in humans, the nature of this relation remains undefined. To investigate the impact of MAO B deficiency on the emotional responses elicited by environmental cues, we tested $M A O B$ knockout $(K O)$ mice in a set of behavioral assays capturing different aspects of anxiety-related manifestations, such as the elevated plus maze, defensive withdrawal, marble burying, and hole board. Furthermore, MAO B KO mice were evaluated for their exploratory patterns in response to unfamiliar objects and risk-taking behaviors. In comparison with their wild-type (WT) littermates, MAO B KO mice exhibited significantly lower anxiety-like responses and shorter latency to engage in risk-taking behaviors and exploration of unfamiliar objects. To determine the neurobiological bases of the behavioral differences between WT and MAO B KO mice, we measured the brain-regional levels of PEA in both genotypes. Although PEA levels were significantly higher in all brain regions of $\mathrm{MAO} B \mathrm{KO}$ in comparison with WT mice, the most remarkable increments were observed in the striatum and prefrontal cortex, two key regions for the regulation of behavioral disinhibition. However, no significant differences in transcript levels of PEA's selective receptor, trace amine-associated receptor I (TAARI), were detected in either region. Taken together, these results suggest that MAO B deficiency may lead to behavioral disinhibition and decreased anxiety-like responses partially through regional increases of PEA levels.
\end{abstract}

Neuropsychopharmacology (2009) 34, 2746-2757; doi: I0.1038/npp.2009. I 8; published online 26 August 2009

Keywords: monoamine oxidase B; mice; behavioral disinhibition; anxiety; phenylethylamine

\section{INTRODUCTION}

Monoamine oxidase (MAO) (EC 1.4.3.4) is the key enzyme catalyzing the oxidative deamination of monoamine neurotransmitters in the central nervous system. Although the two MAO isoenzymes, $\mathrm{A}$ and $\mathrm{B}$, share about $70 \%$ homology and follow the same kinetic mechanism (Bortolato et al, 2008; Shih et al, 1999a), they exhibit significant differences in substrate and inhibitor specificities: whereas MAO A displays high affinity for serotonin (5-hydroxytryptamine, $5-\mathrm{HT}$ ) and norepinephrine (NE), and is inhibited by low doses of clorgyline, MAO B prefers $\beta$-phenylethylamine (PEA) and is selectively inhibited by small concentrations of l-deprenyl (Bortolato et al, 2008; Shih et al, 1999a). This neurochemical divergence implies that the two MAO isoenzymes likely exert different functions in the organization of brain activity and neurophysiological processes.

*Correspondence: Dr JC Shih, Department of Pharmacology and Pharmaceutical Sciences, University of Southern California, Rm. 5I8, 1985 Zonal Avenue, PSC 512, Los Angeles, CA 90089, USA,

Tel: + | 323442 |44I, Fax: + I 323442 3229, E-mail: jcshih@usc.edu

${ }^{3}$ These authors contributed equally to this work.

Received 9 April 2009; revised 15 July 2009; accepted 24 July 2009
Their specific roles in behavioral regulation, however, remain partially elusive. A powerful tool to elucidate the influence of MAO A and MAO B on behavior is afforded by mice carrying genetic knockout (KO) of either enzyme (Cases et al, 1995; Chen et al, 2004; Grimsby et al, 1997; Scott et al, 2008).

Monoamine oxidase A KO mice have been the focus of extensive phenotypic characterization (Bortolato et al, 2008; Shih et al, 1999a). Among other features, these mutants have high brain levels of 5-HT, DA, and NE and exhibit a rather complex behavioral phenotype, including impulsive aggression, low exploratory activity, and greater retention of aversive memories (Cases et al, 1995; Kim et al, 1997; Popova et al, 2001; Shih et al, 1999b). This set of behavioral abnormalities strikingly mirrors the nosographic characteristics of Brunner syndrome, a genetic disorder induced by a nonsense mutation of MAO A gene and featuring antisocial conduct and mental retardation (Brunner et al, 1993).

In contrast, the neurobiological and behavioral implications of MAO B deficiency remain poorly understood. MAO B KO mice display high brain levels of PEA, but not 5-HT, DA, or NE. PEA has been implicated in the regulation of emotional responses, including exploratory activity, arousal, and behavioral reinforcement (Sabelli and Javaid, 
1995). Recently, several lines of investigations have ascertained that some of the actions of PEA are mediated by the activation of trace amine-associated receptor 1 (TAAR1) (Borowsky et al, 2001; Lindemann and Hoener, 2005), which has been implicated in the regulation of DA signaling in the striatum (Lindemann et al, 2008; Wolinsky et al, 2007; Xie and Miller, 2009).

In keeping with these premises, MAO B KO mice exhibit decreases in behavioral parameters reflective of stress susceptibility (Bohus et al, 1987; Korte et al, 1996; Louvart et al, 2005), such as forced-swim immobility and locomotor habituation (Grimsby et al, 1997; Lee et al, 2004). Low MAO B platelet activity in humans has been consistently correlated with extraversion and novelty-seeking traits, yet a causal relationship between the two phenomena has not been established (Oreland, 1993).

This scenario suggests that MAO B deficiency may result in behavioral disinhibition, a temperamental tendency characterized by novelty- and sensation-seeking personality and negligence of potential or actual dangers (Iacono et al, 2003). To verify this possibility, in this study we analyzed the behavioral performances enacted by MAO B KO mice in a number of models exploring different facets of responsiveness to contextual stimuli, including anxiety-like responses, exploratory activity, and risk-taking behaviors.

\section{MATERIALS AND METHODS}

\section{Animals}

We used 4-5 months old, experimentally naïve male $129 / \mathrm{Sv}$ mice ( $n=166 ; 83 /$ genotype), weighing $30-35 \mathrm{~g}$. MAO B KO mice and wild-type (WT) littermates were generated as previously described (Grimsby et al, 1997). Animals were housed in group cages with ad libitum access to food and water. The room was maintained at $22^{\circ} \mathrm{C}$, on a $12 \mathrm{~h}: 12 \mathrm{~h}$ light/dark cycle, with lights off at 0600 hours. Before behavioral testing, all animals were found to display equivalent physical and neurological characteristics. All experimental procedures were in compliance with the National Institute of Health guidelines and approved by the University of Southern California Animal Use Committees. To avoid potential carryover effects, each animal was used only once throughout the study. Litter effects were minimized by using mice from at least three different litters in each behavioral test.

\section{Elevated Plus Maze}

The test was performed as previously described (Wall and Messier, 2000), under either dim (10 lux) or bright (300 lux) environmental light. Briefly, the apparatus was made from black Plexiglas with a light gray floor and consisted of two open $(25 \times 5 \mathrm{~cm})$ and two closed arms $(25 \times 5 \times 5 \mathrm{~cm})$, which extended from a central platform $(5 \times 5 \mathrm{~cm})$ at $60 \mathrm{~cm}$ from the ground. Mice ( $n=17 /$ genotype) were individually placed on the central platform facing an open arm, and their behavior was observed for $5 \mathrm{~min}$ by an experimenter unaware of the genotype. An arm entry was counted when all the four paws were inside the arm. Behavioral measures included: time spent and entries into each partition of the elevated plus maze, number of fecal boli.

\section{Defensive Withdrawal}

We used a variation of the protocol described by Bortolato et al (2006). Mice $(\mathrm{WT}=7$; MAO B KO=10) were individually placed inside a cylindrical aluminum chamber $(7 \mathrm{~cm}$ diameter $\times 11 \mathrm{~cm}$ length) located along one of the four walls of a dimly lit (10 lux) black Plexiglas open field $(40 \times 40 \times$ $40 \mathrm{~cm}$ ), with the open end facing the center. Mice were allowed to freely explore the environment for $15 \mathrm{~min}$. Behaviors were recorded and monitored by an observer unaware of the genotype. Behavioral measures included: latency to exit the chamber; transitions between the chamber and open field; time spent in the chamber; head pokes out of the chamber; crossings (on a $4 \times 4$ square grid superimposed onto the video image of the open field); and velocity (ratio of crossings to time spent in the open field).

\section{Marble Burying}

Testing was performed using a modification of the methods described by Hirano et al (2005). Mice (WT $=20$; MAO B $\mathrm{KO}=13$ ) were individually placed in dimly lit (10 lux) Makrolon cages $(35 \times 28 \mathrm{~cm})$, with $5 \mathrm{~cm}$ of fine sawdust, for a 30-min acclimatization period. Subsequently, animals were briefly removed and 20 marbles $(1 \mathrm{~cm}$ diameter) were placed in each cage, on top of the sawdust. Mice were then returned to the cages, and their behavior was video recorded for the following $30 \mathrm{~min}$. Measures included the number of buried marbles, and the number and total duration of digging bouts. A marble was considered buried if at least two-thirds of its surface area was covered in sawdust. General activity was analyzed by counting the crossings of a grid ( $5 \times 4$ squares), as described above.

\section{Hole Board}

We used a gray Plexiglas platform $(40 \times 40 \mathrm{~cm})$ raised to a height of $15 \mathrm{~cm}$ from the floor of a transparent Plexiglas box $(40 \times 40 \times 40 \mathrm{~cm})$ in a dimly lit room (10 lux). The platform consisted of 16 equivalent square compartments (12 peripheral and 4 central), each featuring a central circular hole $(2.5 \mathrm{~cm}$ diameter $)$. Mice $(\mathrm{WT}=8 ; \mathrm{MAO} \mathrm{B}$ $\mathrm{KO}=12$ ) were individually placed in the center and their behavior was recorded for $6 \mathrm{~min}$. Behaviors were measured diachronically in 2-min intervals, and included the number of crossings between compartments, and the time spent and number of head pokes in the peripheral and central compartments.

\section{Novel Object Exploration}

We used a modified version of the protocol described by Bortolato et al (2009). Mice (WT $=7, \mathrm{MAO} \mathrm{B} \mathrm{KO}=8)$ were individually acclimatized to a dimly lit (10 lux) gray Plexiglas cubic box $(20 \times 20 \times 20 \mathrm{~cm})$ for $15 \mathrm{~min}$. Twentyfour hours later, animals were exposed to two novel black plastic cylinders $(8 \mathrm{~cm}$ tall $\times 3.5 \mathrm{~cm}$ in diameter $)$, affixed to the floor and symmetrically placed at $6 \mathrm{~cm}$ from the two nearest walls. Mice were placed in a corner, facing the center and at equal distance from the two objects. Their start position was rotated and counterbalanced for each genotype throughout the test. Behaviors were videotaped for $15 \mathrm{~min}$. 
Analysis included number and total duration of exploratory approaches, latency to the first exploration, and the number of crossings (measured as described in the Defensive Withdrawal section). Exploration was defined as sniffing or touching either of the two objects with the snout; sitting on the object was not considered exploration. The time spent in the central 4 squares and the object areas (defined as a $1.75 \mathrm{~cm}$-wide annulus concentric to the cylinders) was also measured.

\section{Novelty-Induced Grooming}

Mice $(\mathrm{WT}=8$, MAO B $\mathrm{KO}=7)$ were placed in a dimly lit (10 lux) Makrolon cage $(35 \times 28 \mathrm{~cm})$ for $30 \mathrm{~min}$. After their removal, five voluminous objects (different for size, shape, and color) were attached to the bottom of one-half of the cage (object area). Animals were returned to the empty half of the cage and left undisturbed for $20 \mathrm{~min}$. Time spent in the object area and grooming bouts and duration were recorded and analyzed by an observer unaware of the genotype.

\section{Wire-Beam Bridge}

The apparatus consisted of a $30-\mathrm{cm}$ high Plexiglas platform and a $50-\mathrm{cm}$ high Plexiglas wall, oppositely placed at $30 \mathrm{~cm}$ distance. The platform was surmounted by an $8-\mathrm{cm}$ deep enclosure, with a square $(13 \times 13 \mathrm{~cm})$ opening facing the wall and placed right above the edge of the platform. Following $24 \mathrm{~h}$ of isolation and food deprivation, mice $(\mathrm{WT}=6 ; \mathrm{MAO} \mathrm{B} \mathrm{KO}=5)$ were individually placed in the enclosure, under dim (10 lux) light conditions, and returned to their cage after $10 \mathrm{~min}$. The edge of the platform and the wall were then connected by a horizontal, unrailed bridge $(1.25 \times 30 \mathrm{~cm})$, made in black aluminum wire, consisting of two parallel beams (thickness: $0.01 \mathrm{~cm}$ ) perpendicularly connected by 24 equally distanced cross-ties $(1.25 \mathrm{~cm}$ long). The bridge was moderately flexible with a downward deflection of $1 \mathrm{~cm}$ per $100-\mathrm{g}$ load at the center point. A circular plastic dish $(6 \mathrm{~cm}$ in diameter) containing six food pellets (approximately $20 \mathrm{~g}$ ) was attached onto the end of the bridge adjacent to the wall. Mice were placed in the enclosure and their behavior was recorded for $10 \mathrm{~min}$. Behavioral measures included the latencies to access the bridge (with all four paws on it) and to reach the food, as well as the sniffing frequency (calculated as the ratio between the sniffing approaches to the bridge before the actual access to it and the latency to access the bridge).

\section{PEA Level Determination}

$\beta$-Phenylethylamine levels were determined as indicated by Grimsby et al (1997). Briefly, brain regions of WT $(n=6)$ and MAO B KO $(n=7)$ mice were identified with a stereotaxic atlas (Franklin and Paxinos, 1997), excised and homogenized in $0.5 \mathrm{~N}$ perchloric acid solution with $\left[\mathrm{H}^{2}\right] \mathrm{PEA}$ as an internal standard. PEA was extracted with diethyl ether, derivatized with pentafluoropropionic anhydride and analyzed using a gas chromatograph directly interfaced with a mass-selective detector (Hewlett-Packard, Palo Alto, CA). Base peaks at 104 and $107 \mathrm{~m} / \mathrm{z}$ were used for detection of PEA and the internal standard, respectively.

\section{TAAR1 Receptor mRNA Level Determination}

RNA was extracted from the striatum and prefrontal cortex of WT and MAO B KO mice ( $n=4 /$ genotype) using Trizol (Invitrogen, Carlsbad, CA). Two micrograms of total RNA were used in first-strand cDNA synthesis with M-MLV reverse transcriptase (Promega, Madison, WI) according the manufacturers instructions. The transcript was amplified with specific primers (TAAR1-F: 5'-ATGCATCTTTGCC ACGCTATC-3', TAAR1-R: 5'-TCAAGGCTCTTCTGAACC-3') by using IQTM SYBR Green Supermix (Bio-Rad, Hercules, CA). PCRs were performed using $1 \mu \mathrm{l}$ of $20 \times$ diluted cDNA with one cycle of $94^{\circ} \mathrm{C}$ for $3 \mathrm{~min}$, followed by 40 cycles of amplification at $94^{\circ} \mathrm{C}$ for $30 \mathrm{~s}, 62^{\circ} \mathrm{C}$ (annealing temperature) for $30 \mathrm{~s}$, and $72^{\circ} \mathrm{C}$ for $30 \mathrm{~s}$. TAAR1 mRNA expression was normalized to $18 \mathrm{~S}$ rRNA levels (Boda et al 2009). Relative comparison of gene expression between WT and MAO B KO mice was determined as described by Rieu and Powers (2009).

\section{Statistical Analysis}

Statistical analyses on behavioral parameters were performed with one-way or two-way ANOVAs, as appropriate, followed by Tukey's test with Spjøtvoll-Stoline correction for post hoc comparisons. Normality and homoscedasticity of data distribution were verified using the KolmogorovSmirnov and Bartlett's test. Nonparametric comparisons were carried out by Mann-Whitney test. Significance threshold was set at $P=0.05$.

\section{RESULTS}

\section{Elevated Plus Maze}

In earlier reports, we documented that MAO B KO and WT mice do not display significant differences in anxietyrelated parameters in the elevated plus-maze (such as the number of entries and the time spent in the open arms), under light conditions analogous to those kept in the housing room (300 lux) (Grimsby et al, 1997). Nevertheless, cogent evidence has shown that high levels of environmental illuminance exacerbate the anxiogenic properties of the open arms of the elevated plus maze (Dawson and Tricklebank, 1995). These premises prompted us to speculate that dim light conditions (10 lux) may be more appropriate to unravel subtle behavioral alterations displayed by MAO B KO mice in this paradigm. Indeed, under these conditions, MAO B KO mice did exhibit significantly more open arm entries (Figure 1a) $(\mathrm{F}(1,18)=4.48, P<0.05)$ and spent a longer time in the open arms (Figure 1b) $(\mathrm{F}(1,18)=4.69, P<0.05)$ in comparison with their WT counterparts. MAO B KO mice also spent a significantly shorter time on the center platform (Figure 1d) $(\mathrm{F}(1,18)=4.89, P<0.05)$. In contrast, the two genotypes exhibited comparable entries in the center (Figure 1c) $(\mathrm{F}(1,18)=1.63$, NS), as well as both entries $(\mathrm{F}(1,18)=0.51$, NS) and time spent $(F(1,18)=0.08$, NS) in the closed arms (Figure 1e and f). The reduction in anxiety-like responses in MAO B KO mice was also confirmed by their lower number of fecal boli excreted during the testing session (Figure 1g) $(F(1,18)=7.24, P<0.05)$. The behavioral variability between 

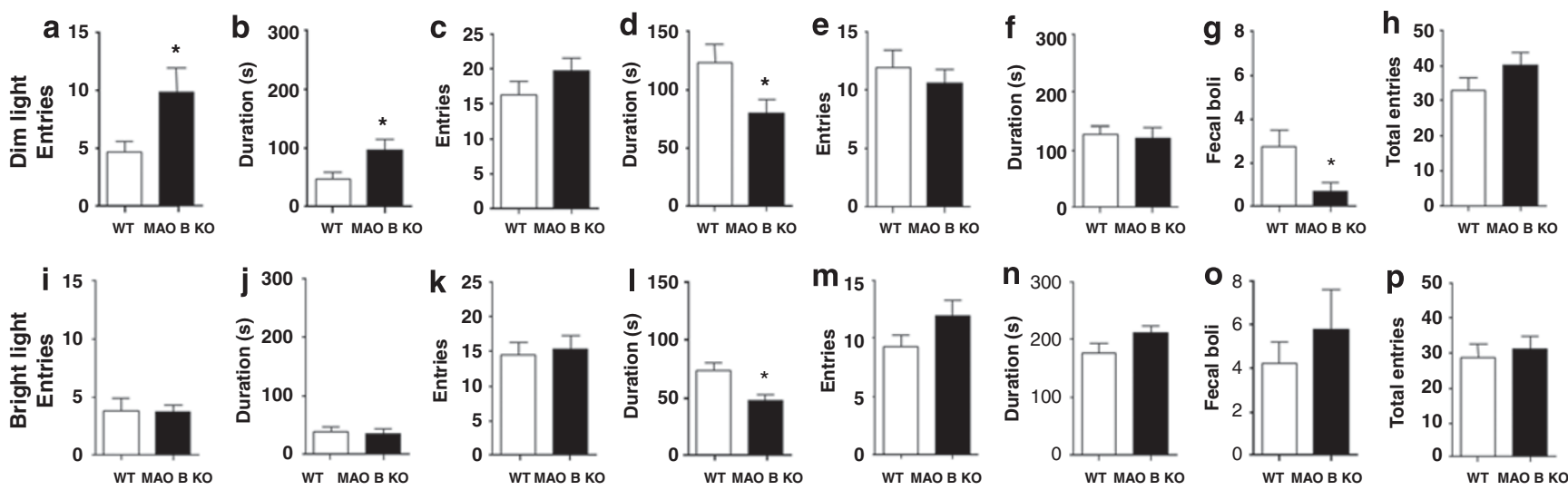

Open arms

Center platform

Closed arms

Figure I MAO B KO mice exhibit significant reductions in anxiety-like behaviors in the elevated plus maze under dim (a-h), but not bright (i-p) light conditions. All values are represented as means $\pm S E M$. $* P<0.05$, compared with wild-type $(W T)$ controls. For more details, see Results section.
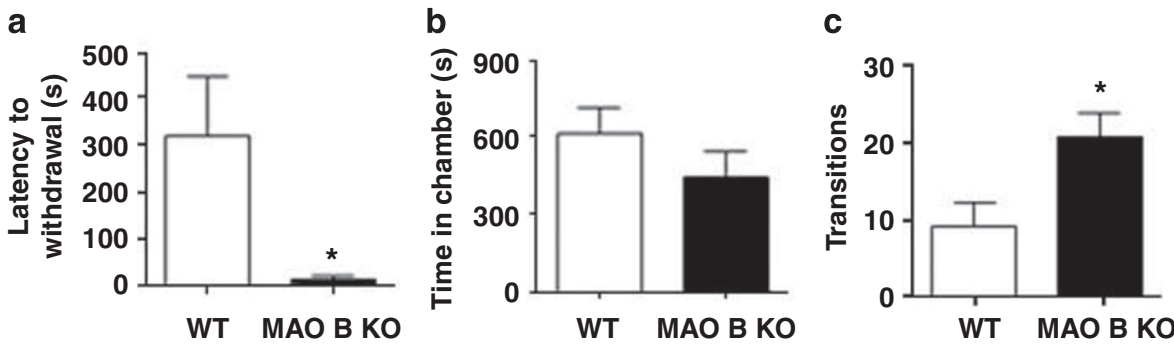

Figure 2 MAO B KO mice display decreased anxiety-like behaviors in the defensive withdrawal paradigm. All values are represented as means \pm SEM. $* P<0.05$, compared with WT mice. For more details, see Results section.

genotypes did not reflect differences in activity, as shown by the equivalent number of total entries $(F(1,18)=1.89$, NS) (Figure 1h).

In a second set of experiments carried out under bright light conditions (300 lux) with a different set of animals, we confirmed the lack of substantial behavioral differences between WT and MAO B KO mice (Figure 1i-p). However, the latter spent a shorter time on the center platform (Figure 1l) $(\mathrm{F}(1,14)=8.66, P<0.05)$, in a manner similar to their homogenotypic counterparts tested under dim light.

\section{Defensive Withdrawal}

To further characterize the ethological significance of the behavioral alterations displayed by MAO B KO mice in the elevated plus maze, we tested them in another well-validated model of anxiety, the defensive withdrawal paradigm. This test harnesses the conflict between the natural drive of rodents to explore a novel open arena and their tendency to retreat into an enclosed chamber, based on their degree of perceived threat (Takahashi et al, 1989). MAO B KO mice showed a significantly reduced latency to withdraw from the chamber (Figure $2 \mathrm{a})(\mathrm{U}(7,10)=10, P<0.05)$ and a marked reduction, albeit not significant, in time spent inside the chamber (Figure $2 \mathrm{~b})(\mathrm{F}(1,15)=3.17, P<0.10)$. The number of transitions between the chamber and the open arena was also higher for MAO B KO mice (Figure 2c) $(\mathrm{F}(1,15)=7.4$, $P<0.05)$. However, no differences between MAO B KO and
WT mice were detected in head pokes $((\mathrm{WT}=23.6 \pm 3.6$; MAO B $\mathrm{KO}=22.3 \pm 7.1) \quad(\mathrm{F}(1,15)=0.03, \mathrm{NS}))$, velocity in the open field (defined as the ratio between the number of crossings and the time spent in the arena) $((\mathrm{WT}=0.15 \pm 0.06 ; \mathrm{MAO} \mathrm{B} \mathrm{KO}=0.22 \pm 0.03) \quad(\mathrm{F}(1,15)=$ $1.49, \mathrm{NS}))$, and fecal boli $((\mathrm{WT}=3.1 \pm 1.0 ; \mathrm{MAO} \quad \mathrm{B}$ $\mathrm{KO}=1.6 \pm 0.5)(\mathrm{F}(1,15)=1.81, \mathrm{NS}))$.

\section{Marble Burying}

To further substantiate the hypothesis that MAO B KO mice show decreased anxiety-like behaviors, we used the marble burying paradigm. This model has been recently shown to capture aspects of environmental reactivity different from those assessed in the conflict-based assays (Thomas et al, 2009). Unlike their WT counterparts, MAO B KO mice buried a remarkably low number of marbles (Figure 3a) $(\mathrm{U}(20,13)=72, P<0.05)$, but displayed equivalent activity (Figure $3 \mathrm{~b})(\mathrm{F}(1,24)=0.27, \mathrm{NS})$. The reduction in buried marbles was paralleled by a significant decrease in digging bouts (Figure 3c) $(\mathrm{F}(1,26)=7.63, P<0.05)$ and duration (Figure 3d) $(U(19,10)=34, P<0.01)$. In spite of their dramatic reduction in digging behaviors, MAO B KO mice approached and actively explored the marbles, with an average frequency of $4.38 \pm 0.01$ exploratory bouts/min. This parameter, however, could not be efficiently compared across genotypes, as WT mice engaged in significantly more marble-burying behavior. 


\section{Hole-Board Test}

Following the detection of reduced anxiety-related manifestations in MAO B KO mice, we assessed the potential impact of these alterations on the exploratory activity by testing the animals in the hole-board paradigm (Casarrubea et al, 2008). The total number of head dips was comparable between MAO B KO and WT (Figure 4a) $(\mathrm{F}(1,18)=0.28$, NS). Nevertheless, MAO B KO mice performed significantly more head dips in the center than WT mice (Figure 4b) $(\mathrm{F}(1,17)=4.52, P<0.05)$, a behavior that has been interpreted as reflective of anxiolysis (Hranilovic et al, 2005).
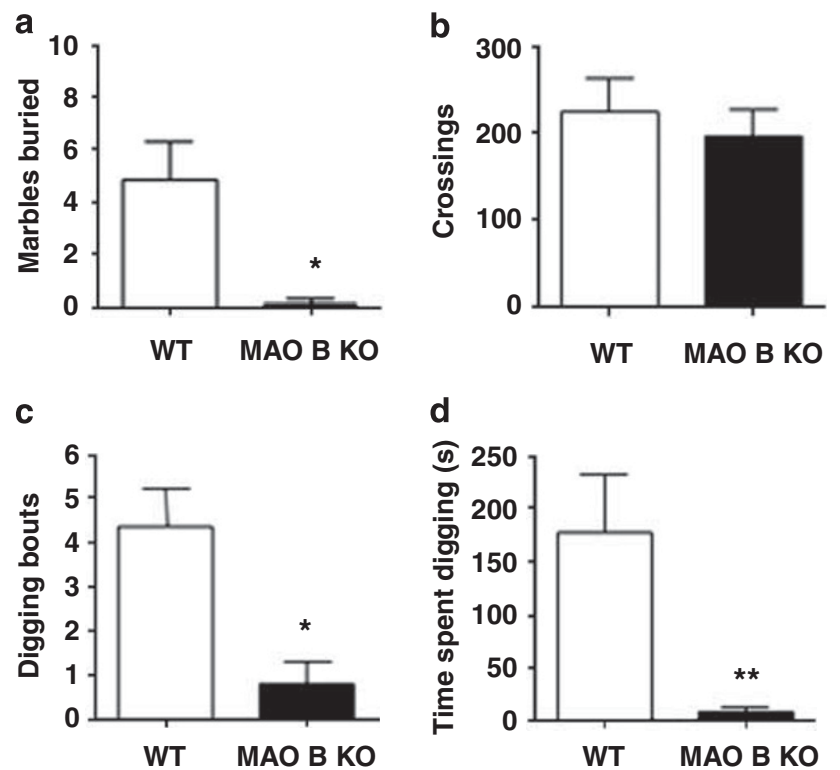

Figure $3 \mathrm{MAO} B \mathrm{KO}$ mice exhibit a reduction in marble-burying and digging behaviors. All values are represented as means $\pm \mathrm{SEM}$. $* P<0.05$, $* * P<0.0$ I compared with WT controls. For more details, see Results section.
Peripheral head dips were comparable between genotypes (Figure 4c) $\quad(\mathrm{F}(1,18)=2.07$, NS). No other significant differences were found in either locomotor activity $(\mathrm{F}(1,16)=0.27, \mathrm{NS})$ or time spent in the central quadrants $((\mathrm{WT}=29.2 \pm 6.6 ; \mathrm{MAO}$ B KO $=76.5 \pm 29.8)(\mathrm{F}(1,16)=1.11$, NS)). Although the latency to initial head dip was equivalent across genotypes, (Figure $4 \mathrm{~d})(\mathrm{F}(1,18)=0.06$, NS) MAO B KO mice exhibited a significantly decreased latency to the first head dip in one of the central holes (Figure 4e) $(\mathrm{U}(8,12)=17, P<0.05)$. Latency to the first peripheral head dip was statistically equivalent in WT and MAO B KO mice (Figure $4 \mathrm{f})(\mathrm{U}(8,11)=36, \mathrm{NS})$.

\section{Novel Object Exploration}

During both the acclimation phase and the exposure to novel objects, MAO B KO and WT mice exhibited similar magnitude and patterns of locomotor activity (data not shown). MAO B KO mice approached the objects with a significantly reduced latency (Figure 5a) $(\mathrm{U}(7,8)=6$, $P<0.01)$ and explored them for a significantly longer time (Figure $5 \mathrm{~b}) \quad(\mathrm{F}(1,13)=5.17, P<0.05)$. In contrast, the number of exploratory approaches was analogous between genotypes $\quad((\mathrm{WT}=80.9 \pm 19.3 ; \quad \mathrm{MAO} \quad \mathrm{B} \quad \mathrm{KO}=95.6 \pm 8.3)$ $(\mathrm{F}(1,13)=0.96, \mathrm{NS}))$. Statistical analysis also showed a trend for MAO B KO mice to spend longer time in object areas $\quad((\mathrm{WT}=161.1 \pm 28.5 ; \quad \mathrm{MAO} \quad \mathrm{B} \quad \mathrm{KO}=263.6 \pm 36.9)$ $(\mathrm{F}(1,13)=3.97, P<0.10))$. These results suggest that MAO $\mathrm{B}$ KO mice may be characterized by a stronger drive (or a reduced timidity) to explore unfamiliar objects.

\section{Novelty-Induced Grooming}

Earlier studies (Kalueff and Tuohimaa, 2004) and preliminary observations obtained by our group have shown that $129 / \mathrm{Sv}$ mice display poor spontaneous grooming activity in response to novel environmental stimuli. Thus,
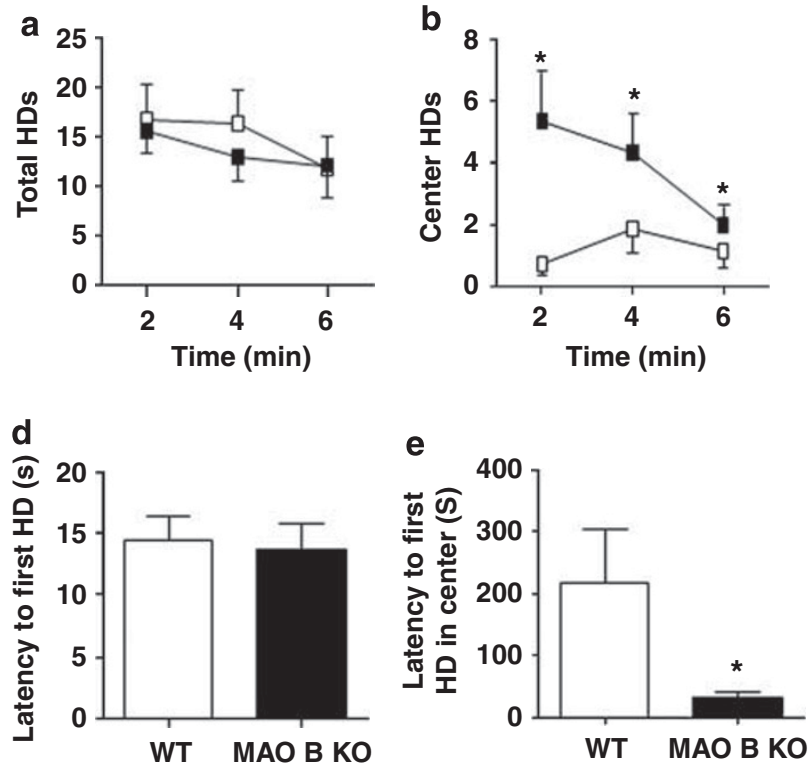
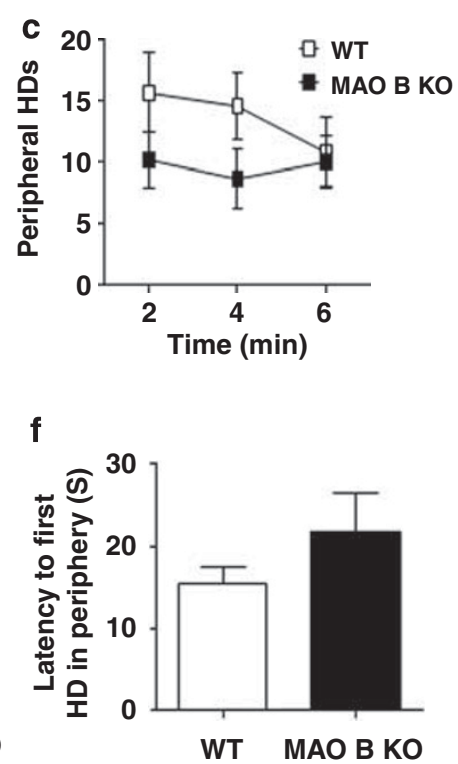

Figure $4 \mathrm{MAO}$ B KO mice explore central holes with longer duration and shorter latency in the hole-board test. All values are represented as means $\pm \mathrm{SEM}$. $* P<0.05$, compared with WT controls. For more details, see Results section. 

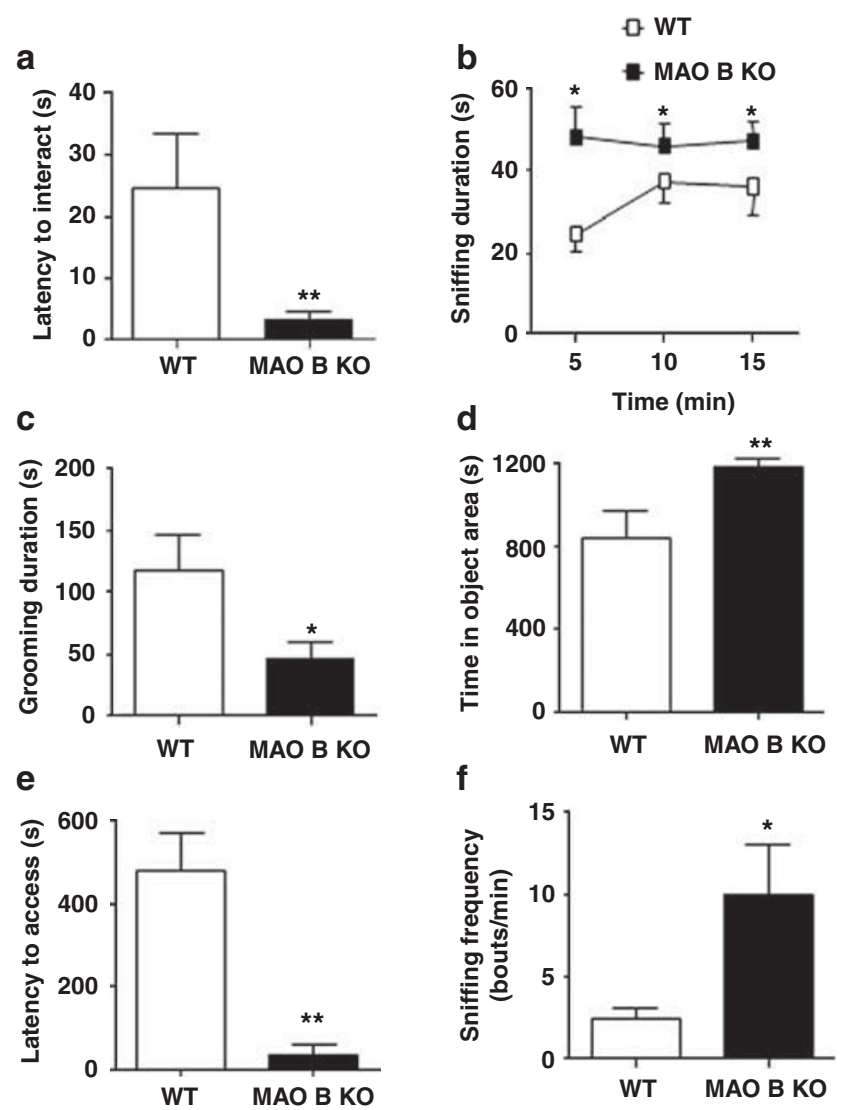

Figure 5 MAO B KO mice display higher levels of exploration targeting novel objects and risk-taking behavior in the wire-beam bridge test. All values are represented as means \pm SEM. $* P<0.05$, ** $P<0.01$ compared with WT littermates. For more details, see Results section.

we optimized our protocol to detect novelty-induced grooming and avoidance by placing five voluminous objects in one-half of the cage. MAO B KO mice spent significantly less time grooming (Figure $5 \mathrm{c})(\mathrm{F}(1,12)=4.93, P<0.05)$, but engaged in a similar number of grooming bouts $\quad((\mathrm{WT}=7.71 \pm 1.69 ; \quad \mathrm{MAO} \quad \mathrm{B} \quad \mathrm{KO}=5.71 \pm 1.26)$ $(\mathrm{F}(1,12)=0.78, \mathrm{NS}))$ in comparison with their WT counterparts. Furthermore, MAO B KO mice spent a significantly longer time in the object area (Figure $5 d)(U(8,7)=6$, $P<0.01)$. These results confirm that MAO B KO mice display less environmental and object-related neophobia than WT mice.

\section{Wire-Beam Bridge Test}

Low levels of platelet MAO B activity have been strongly associated with features of the behavioral disinhibition spectrum, including impulsivity, sensation-seeking, and risk-taking (Hirschfeld-Becker et al, 2003; Ruchkin et al 2005). To capture these elements, we measured the proclivity of animals to cross an unrailed flexible bridge suspended over a $30-\mathrm{cm}$ deep gap, to reach a food reward. MAO B KO mice exhibited a significantly shorter latency to access the bridge (Figure $5 \mathrm{e})(\mathrm{U}(6,5)=1.5, P<0.01)$ and latency to touch the food $((\mathrm{WT}=483.83 \pm 81.64 ; \mathrm{MAO} \mathrm{B}$ $\mathrm{KO}=48.00 \pm 23.66)(\mathrm{U}(6,5)=1, P<0.01))$ to obtain the food reward in comparison with their WT counterparts. In
Table I MAO B KO Mice Exhibit Significantly Higher PEA Levels in all Regions Tested

\begin{tabular}{|c|c|c|}
\hline \multirow{2}{*}{ Region } & \multicolumn{2}{|c|}{ PEA levels } \\
\hline & $\begin{array}{c}\text { WT } \\
(N=7)\end{array}$ & $\begin{array}{c}\text { MAO В КО } \\
\qquad(N=6)\end{array}$ \\
\hline Cortex & $1.68 \pm 0.28$ & $7.4 \pm 0.40$ 米米米 \\
\hline Striatum & $2.24 \pm 0.37$ & $25.8 \pm 3.42$ **** \\
\hline Hippocampus & $3.52 \pm 0.87$ & $9.18 \pm 0.87$ **** \\
\hline Thalamus & $6.55 \pm 0.68$ & $12.5 \pm 2.24 *$ \\
\hline Cerebellum & $2.13 \pm 0.56$ & $7.81 \pm 1.69$ *** \\
\hline
\end{tabular}

All values are represented as means \pm SEM.

${ }^{*} P<0.05$, $* * P<0.01$, **** $P<0.00$ I compared with $\mathrm{WT}$ littermates.

the time before accessing the novel bridge, MAO B KO mice engaged in a significantly higher sniffing frequency towards it (Figure 5f) $(\mathrm{U}(6,5)=2, P<0.05)$ compared with WT mice. These results further support that MAO B KO mice display greater impulsivity, sensation-seeking, and risktaking behaviors than WT mice.

\section{PEA Brain-Regional Levels}

We previously determined that MAO B KO mice feature high brain levels of PEA (Grimsby et al, 1997). To identify the regional determinants of the influence of PEA on the spectrum of behavioral alterations in MAO B KO mice, we examined PEA levels in several regions associated with anxiety and emotional reactivity. MAO B KO mice displayed higher PEA levels in the frontal cortex (MAO B KO/WT ratio: $4.4 ; \mathrm{F}(1,11)=145.44, P<0.001)$, striatum (MAO B KO/ WT ratio: $11.5 ; \mathrm{F}(1,11)=55.20, P<0.001)$, hippocampus (MAO B KO/WT ratio: $2.6 ; \mathrm{F}(1,11)=20.94, P<0.001$ ), thalamus (MAO B KO/WT ratio: $1.9 ; \mathrm{F}(1,11)=7.42$, $P<0.05$ ), and cerebellum (MAO B KO/WT ratio: 3.7; $\mathrm{F}(1,11)=11.67, P<0.01)$ compared with their WT counterparts (Table 1).

\section{TAAR1 Transcript Brain-Regional Levels}

As the most dramatic increase in PEA-regional levels featured by MAO B KO mice was observed in the striatum (1150\% in comparison with WT) and frontal cortex ( $440 \%$ in comparison with WT), we tested the expression of the transcript of its selective receptor, TAAR1, in these regions. Striatal TAAR1 mRNA was comparable between MAO B KO and WT mice (Relative expression: WT: $1 \pm 0.24$; $\mathrm{MAO} \quad \mathrm{B} \quad \mathrm{KO}: 1.37 \pm 0.35) \quad(\mathrm{F}(1,6)=1.16, \quad \mathrm{NS})$. Similarly, no significant difference was identified between both genotypes in mRNA expression in the frontal cortex (relative expression: WT: $1 \pm 0.32$; MAO B KO: $1.54 \pm 0.62$ ) $(\mathrm{F}(1,6)=3.03$, NS)

\section{DISCUSSION}

The major result of this study is that MAO B deficiency in mice leads to behavioral disinhibition in several models 
of contextual anxiety and risk-taking behavior, as well as enhanced novelty-seeking responses with respect to unfamiliar objects. These findings are in substantial agreement with previous cross-sectional investigations, documenting that low platelet MAO B enzymatic activity is correlated with several facets of behavioral disinhibition (Buchsbaum et al, 1976; Oreland, 1993; von Knorring et al, 1984), including novelty- and sensation-seeking personality (Fowler et al, 1980a; Reist et al, 1990; Ruchkin et al, 2005), poor impulse control (Paaver et al, 2007; Skondras et al, 2004 ), and proclivity to engage in risky behaviors (Blanco et al, 1996).

Previous studies indicate that low platelet MAO B activity is highly heritable (Oxenstierna et al, 1986) and may influence behavior since the neonatal stage (Sostek et al, 1981), suggesting that this index may be a genetic determinant for uninhibited personality (Blanco et al, 1996; Oreland and Hallman, 1995). MAO B deficiency in Norrie disease patients was reported to result in no overt physical or mental alterations (Lenders et al, 1996). However, it should be observed that the severe degree of sensory and perceptual impairments induced by Norrie disease (early-onset blindness and progressive hearing loss) most likely masked alterations in environmental reactivity in these subjects.

The role of MAO B in emotional regulation is further supported by a host of clinical studies, showing that chronic administration of $l$-deprenyl exerts mood-enhancing and anxiolytic effects in depression (Mendlewicz and Youdim, 1980; Quitkin et al, 1984; Robinson et al, 2007) and other disorders (Goad et al, 1991; Tariot et al, 1987; Tolbert and Fuller, 1996). Interestingly, $l$-deprenyl (both in acute and chronic administration) elicits only minor or no anxiolyticlike effects in rodents (Commissaris et al, 1995; De Angelis and Furlan, 2000; Nowakowska et al, 2001). The most likely explanation for the apparent discrepancy between these reports and our results lies in the genetic nature of MAO B inactivation examined in this study, which cannot be completely recapitulated by the outcomes of chronic exposure to enzyme inhibitors (Whitaker-Azmitia et al, 1994).

In rodents, emotional reactivity and novelty-seeking behavior is measured as a function of the exploratory activity toward unfamiliar environments and objects (Oreland, 1993; Robinet et al, 1998; Fornai et al, 1999). Accordingly, the validity of novelty-induced tasks as animal models of anxiety (Pellow et al, 1985; Takahashi et al, 1989) is based on the opposition between exploratory drive and neophobia-derived avoidance (Dellu et al, 2000). This contrast can be influenced by certain environmental manipulations, such as the variation of light intensity in the experimental room (Dawson and Tricklebank, 1995).

In a dimly lit elevated plus maze, MAO B KO mice displayed a significant reduction in anxiety-like behavior, signified by an increase in open-arm time and entries, as well as a reduction of defecation frequency (Tarantino and Bucan, 2000). In contrast, a bright illuminance level (300 lux) failed to elicit significant differences between MAO B KO and WT mice in these anxiety-related parameters, possibly due to 'floor effects'.

Dim light conditions have been extensively used to capture fine modifications in anxiety-like behaviors
(Bortolato et al, 2006; Bourin et al, 2001; Genn et al, 2003; Löw et al, 2000; Rubino et al, 2008). In this study, a low environmental luminosity provided an optimal setting to reveal the reduction in anxiety-like behaviors in MAO B KO mice, suggesting that the deficiency of this enzyme results in subtle, context-dependent changes in anxiety regulation. This contention is also supported by the observation that the behavioral abnormalities in MAO B KO mice could not be detected in their home cages (data not shown), but only in the presence of novel objects or contexts.

In the defensive withdrawal test, MAO B KO mice exhibited reductions in latency to exit the chamber and in transitions between the chamber and the open arena. Both parameters are highly dependable indices to measure defensive behaviors (Arborelius and Nemeroff, 2002), and their reduction is considered reflective of reduced fearfulness or deficits in threat detection. This interpretation is also supported by the significant decline in time spent on the elevated plus maze central platform, which has been suggested to indicate potential impairments in decisionmaking or impulse-control processes (Rodgers et al, 1992; Trullas and Skolnick, 1993).

The reduction in anxiety-related responses in MAO B KO mice was also confirmed by the nearly complete abrogation of their marble-burying behavior. This murine assay has been validated to explore different aspects of anxiety-like behaviors than conflict-based paradigms (Thomas et al, 2009), in a manner sensitive to anxiolytic and antidepressant drugs (Borsini et al, 2002; Broekkamp et al, 1986; Nicolas et al, 2006; Njung'e and Handley, 1991). Marble burying reflects digging activity, but is independent from locomotion or exploration (Gyertyan, 1995; Thomas et al, 2009); Accordingly, MAO B KO mice dug significantly less than WT counterparts, but displayed a comparable number of crossings.

Our findings on the patterns of exploratory activity in the hole-board test are also supportive of the reduced anxietylike behaviors in MAO B KO mice. Although overall locomotor activity was comparable between genotypes, MAO B KO mice manifested a lower level of avoidance toward the central holes, indicating a reduction in thigmotactic behavior (Hranilovic et al, 2005) and novelty-related aversion (Brown and Nemes, 2008). As animals were initially placed in the center of the hole board, the increased number of central head dips may also reflect an enhancement in perseverative behavior, following exploration of the first central hole. Nevertheless, this possibility is partially tempered by the equivalent latency to the first peripheral head dip between the two genotypes, which was accompanied by a similar locomotor activity (and number of head dips in the external zone) in the first 2-min period of testing. This phenomenon most likely indicates that MAO B KO mice did not exhibit an initial tendency to neglect holes in the external zone of the hole board.

The possibility that the behavior enacted by MAO B KO mice may be reflective of low neophobia is also supported by their reaction to unfamiliar objects. Indeed, in comparison to their WT counterparts, MAO B KO mice exhibited a stronger inclination to explore novel objects (with higher duration and lower latency), as well as lower levels of novelty-induced grooming and reduced avoidance of object-laden areas. Alternatively, these responses may also 
signify poor impulse control and higher drive toward risktaking behaviors in MAO $\mathrm{B}$ KO mice. In rodents, impulsivity is generally studied by means of go/no-go tests, which measure the capacity to withhold behavioral reactions (Dalley et al, 2008). However, as these tasks are based on operant responses, they cannot be dependably used in MAO B KO mice, due to alterations in mnemonic acquisition in these mice (Bortolato et al, in preparation). To obviate this pitfall, we tested MAO B KO mice in the wire-beam bridge task, an assay devised to verify their inclination to engage in risk-taking behaviors (such as walking on a novel, flexible bridge placed above a $30 \mathrm{~cm}$ deep gap) to reach a rewarding goal. The prevalence of motivational drives over the ability to adjust behavioral responses to contextual elements is considered a key feature of impulsiveness (Jentsch and Taylor, 1999; Bechara et al, 2000). On exposure to the novel bridge, MAO B KO mice exhibited a significantly shorter latency to both access and cross the bridge to reach the food reward compared with WT mice. This divergence most likely signifies enhanced risk-taking behavior in $\mathrm{MAO} \mathrm{B} \mathrm{KO}$ mice, and may reflect alterations in decision-making processes and emotional regulation in this genotype (Llewellyn, 2008). Interestingly, MAO B KO mice engaged in a significantly higher frequency of sniffing bouts toward the bridge than WT mice, showing that their shorter latency to bridge access was not reflective of inadequate exploration of the bridge itself or lower risk assessment.

In a previous report, we described that $\mathrm{MAO} \mathrm{B} \mathrm{KO}$ mice exhibited lower immobility in the forced swim test than WT counterparts (Grimsby et al, 1997). In mutant mice, this behavior has been associated with either enhanced (Parks et al, 1998) or reduced anxiety-like behavior (Bale and Vale, 2003; Tschenett et al, 2003). Our present findings help define the conceptual framework for the interpretation of the stress response exhibited by MAO B KO mice, suggesting that their behavior in the forced swim paradigm may reflect their enhanced ability to counteract the stress induced by novel contextual factors and hazardous situations. Substantial evidence has shown that the increased mobility in forced swim test is associated with a lower vulnerability to stress-induced anhedonia and depression (Strekalova et al, 2004; Trzctñska et al, 1999), as well as decreased neophobia (Gundersen and Blendy, 2009). Accordingly, decreased grooming activity has been shown to be a dependable criterion to measure increased inclination to cope with stress (Kalueff and Tuohimaa, 2004). The higher resistance to stress in MAO $\mathrm{B} \mathrm{KO}$ mice is also corroborated by their significantly lower levels of hyperthermia (Bouwknecht et al, 2007) induced by $2 \mathrm{~h}$ of physical restraint, in comparison with WT littermates (WT: $\Delta \mathrm{T}: 1.09 \pm 0.13^{\circ} \mathrm{C}$; MAO B KO: $\left.\Delta \mathrm{T}: 0.12 \pm 0.22^{\circ} \mathrm{C} ; P<0.01\right)$ (unpublished data).

Monoamine oxidase $\mathrm{B}$ KO mice feature a significant elevation in whole-brain levels of PEA, but not other monoamines (Grimsby et al, 1997). This premise suggests that this trace amine may have a key role in the behavioral alterations induced by MAO B genetic deficiency. Indeed, PEA has been shown to enhance mood and sensory functions in joint administration with MAO B inhibitors (which prevent its degradation) (Sabelli et al, 1994; Sabelli and Javaid, 1995). Furthermore, the synthetic PEA analog amphetamine is known to increase novelty-seeking behaviors and reduce impulse control in both rodents and humans (Evenden and Ryan, 1996; Leyton et al, 2002; Williamson et al, 1997).

In apparent contrast with our findings, acute administration of PEA has been shown to induce anxiety in rodents (Lapin, 1990, 1993). However, congenital, chronic exposure to high PEA levels may reduce anxiety-spectrum responses in MAO B KO mice, probably by the progressive recruitment of processes opposing the anxiogenic effects of this trace amine. Similarly, MAO B KO mice also fail to exhibit other alterations reminiscent of the effects induced by acute PEA administration, such as hyperlocomotion (Mantegazza and Riva, 1963), stereotyped behavior (Moja et al, 1976), and anorexia (Dourish and Boulton, 1981). Final verification of the involvement of PEA in the behavioral performance of MAO B KO mice would require pharmacological manipulations to reduce their PEA levels, such as the inhibition of its synthesis. The accomplishment of this objective, however, is hindered by the lack of substrate specificity of the only PEA-synthesizing enzyme as yet characterized in mice, aromatic $l$-amino acid decarboxylase (EC4.1.1.28) (Kubovcakova et al, 2004; Zucchi et al, 2006). This enzyme catalyzes key reactions in the synthesis of all the other major neurotransmitter systems, such as DA, NE, and 5-HT (Allen et al, 2009), and its inhibition results in a number of nonspecific effects on several brain functions (Fisher et al, 2000).

To partially circumvent these limitations, in this study we have examined the differential expression of PEA levels in several brain regions associated with emotional reactivity. Although the increase in PEA brain levels involves several brain regions of $\mathrm{MAO} \mathrm{B} \mathrm{KO}$ mice, the most marked enhancements in PEA levels were observed in the striatum and prefrontal cortex, two regions extensively implicated in behavioral disinhibition (Johansson and Hansen, 2000; Winstanley et al, 2006).

The involvement of striatum and prefrontal cortex in behavioral disinhibition has been linked to the functional activity of DAergic system (Pattij et al, 2007), suggesting that DA may be implicated in the behavioral alterations in MAO B KO mice. This possibility is supported by a host of studies underscoring the key role of DA in behavioral disinhibition (Black et al, 2002; Megens et al, 1992; van Gaalen et al, 2006) and anxiolysis (Shabanov et al, 2005; Picazo et al, 2009). Previous studies have shown that PEA induces modification of the DA signaling, which may have a role in the behavioral responses mediated by this trace amine (Kuroki et al, 1990; Sotnikova et al, 2004). Interestingly, although MAO B KO mice do not feature alterations of striatal DA synthesis, uptake, and release, they do exhibit alterations in DA receptors in this region (Chen et al, 1999). Furthermore, structural changes in other monoamine systems (such as 5-HT) may also be induced by MAO B deficiency (Whitaker-Azmitia et al, 1994; Oreland et al, 2007).

Emerging evidence points to a role of TAAR1 receptor in the PEA-mediated modulation of DAergic signaling (Xie and Miller, 2009; Lindemann et al, 2008). Although no apparent compensatory changes in TAAR1 receptor expression were detected in either striatum or frontal cortex, the present data cannot allow any final conclusion on the 
functional contribution of this receptor to the behavioral spectrum of MAO B KO mice. Although pharmacological studies with TAAR1 receptor antagonists may help elucidate this issue, these agents are currently unavailable (Sotnikova et al, 2009).

In summary, this study documents that MAO B deficiency in mice results in behavioral disinhibition and reduced neophobia. Our results complement previous findings on the correlation between low MAO B platelet activity and novelty-seeking personality, suggesting a potential causal link between the two phenomena. Nevertheless, both the interpretation of the behavioral phenotype in MAO B KO mice and its translational validity should be considered with caution, in view of several limiting considerations. First, although all the observed abnormalities in MAO B KO mice are evocative of behavioral disinhibition, some of them - such as the increased exploration of novel objects or the decreased marble burying-may also reflect other disturbances in perceptual, attentional, emotional, and cognitive regulation. Further investigations on the impact of MAO B deficiency in these behavioral domains are necessary to elucidate this possibility and further refine our understanding of the complex phenotype exhibited by MAO $\mathrm{B}$ KO mice. Second, the results observed in MAO B KO mice may not be directly applicable to clinical manifestations, in view of the predominance of this isoenzyme in the human brain (Fowler et al, 1980b; Oreland and Gottfries, 1986; Kalaria et al, 1988), which contrasts with its relatively poor expression in rodents (Saura et al, 1996). Third, although dopamine is degraded by MAO A in mice (Cases et al, 1995; Fornai et al, 1999), it is mainly metabolized by MAO B in primates (Garrick and Murphy, 1980), suggesting that the reported alterations in murine phenotype may only partially reproduce the behavioral outcomes of MAO B deficiency in humans. Irrespective of these considerations, these findings strongly support the role of MAO B in the modulation of the neural pathways underlying behavioral disinhibition and emotional reactivity toward contextual stimuli, and warrant further investigations on the function of this enzyme in the regulation of anxiety-related endophenotypes.

\section{ACKNOWLEDGEMENTS}

This work was supported by NIMH Grants, R01MH3908524A1, R01MH67968, R37MH39085 (MERIT Award), and the Boyd and Elsie Welin Professorship. We thank Eric Ka-Wai Hui, Takeshi Kumazawa, Roberto Frau, and Lauren Burgeno for their valuable contributions in the execution of the experiments.

\section{DISCLOSURE}

All authors report no biomedical financial interests or potential conflicts of interest.

\section{REFERENCES}

Allen GF, Land JM, Heales SJ (2009). A new perspective on the treatment of aromatic L-amino acid decarboxylase deficiency. Mol Genet Metab 97: 6-14.
Arborelius L, Nemeroff C (2002). Preclinical models of anxiety. In: Stein D, Hollander E (eds). Textbook of anxiety disorders. American Psychiatric Publishing Inc.: Washington, DC. pp 29-42.

Bale TL, Vale WW (2003). Increased depression-like behaviors in corticotropin-releasing factor receptor-2-deficient mice: sexually dichotomous responses. J Neurosci 23: 5295-5301.

Bechara A, Tranel D, Damasio H (2000). Characterization of the decision-making deficit of patients with ventromedial prefrontal cortex lesions. Brain 123(Part 11): 2189-2202.

Black KJ, Hershey T, Koller JM, Videen TO, Mintun MA, Price JL et al (2002). A possible substrate for dopamine-related changes in mood and behavior: prefronal and limbic effects of a D3-preferring dopamine agonist. Proc Natl Acad Sci USA 99: 17113-17118.

Blanco C, Orensanz-Munoz L, Blanco-Jerez C, Saiz-Ruiz J (1996). Pathological gambling and platelet MAO activity: a psychobiological study. Am J Psychiatry 153: 119-121.

Boda E, Pini A, Hoxha E, Parolisi R, Tempia F (2009). Selection of reference genes for quantitative real-time RT-PCR studies in mouse brain. J Mol Neurosci 37: 238-253.

Bohus B, Benus RF, Fokkema DS, Koolhaas JM, Nyakas C, van Oortmerssen GA et al (1987). Neuroendocrine states and behavioral and physiological stress responses. Prog Brain Res 72: $57-70$.

Borowsky B, Adham N, Jones KA, Raddatz R, Artymyshyn R, Ogozalek KL et al (2001). Trace amines: identification of a family of mammalian G protein-coupled receptors. Proc Natl Acad Sci USA 98: 8966-8971.

Borsini F, Podhorna J, Marazziti D (2002). Do animal models of anxiety predict anxiolytic-like effects of antidepressants? Psychopharmacology (Berl) 163: 121-141.

Bortolato M, Campolongo P, Mangieri RA, Scattoni ML, Frau R, Trezza V et al (2006). Anxiolytic-like properties of the anandamide transport inhibitor AM404. Neuropsychopharmacology 31: 2652-2659.

Bortolato M, Chen K, Shih JC (2008). Monoamine oxidase inactivation: from pathophysiology to therapeutics. Adv Drug Deliv Rev 60: 1527-1533.

Bortolato M, Frau R, Piras A, Luesu W, Bini V, Diaz G et al (2009). Methamphetamine induces long-term alterations in reactivity to environmental stimuli: correlation with dopaminergic and serotonergic toxicity. Neurotox Res 15: 369-393.

Bourin M, Nic Dhonnchadha BA, Claude Colombel M, Dib M, Hascoët M (2001). Cyamemazine as an anxiolytic drug on the elevated plus maze and light/dark paradigm in mice. Behav Brain Res 124: 87-95.

Bouwknecht JA, Spiga F, Staub DR, Hale MW, Shekhar A, Lowry CA (2007). Differential effects of exposure to low-light or highlight open-field on anxiety-related behaviors: relationship to c-Fos expression in serotonergic and non-serotonergic neurons in the dorsal raphe nucleus. Brain Res Bull 72: 32-43.

Broekkamp CL, Rijk HW, Joly-Gelouin D, Lloyd KL (1986). Major tranquillizers can be distinguished from minor tranquillizers on the basis of effects on marble burying and swim-induced grooming in mice. Eur J Pharmacol 126: 223-229.

Brown GR, Nemes C (2008). The exploratory behaviour of rats in the hole-board apparatus: is head-dipping a valid measure of neophilia? Behav Processes 78: 442-448.

Brunner HG, Nelen M, Breakefield XO, Ropers HH, van Oost BA (1993). Abnormal behavior associated with a point mutation in the structural gene for monoamine oxidase A. Science 262: 578-580.

Buchsbaum MS, Coursey RD, Murphy DL (1976). The biochemical high-risk paradigm: behavioral and familial correlates of low platelet monoamine oxidase activity. Science 194: 339-341. 
Casarrubea M, Sorbera F, Crescimanno G (2008). Structure of rat behavior in hole-board: (I) multivariate analysis of response to anxiety. Physiol Behav 96: 174-179.

Cases O, Seif I, Grimsby J, Gaspar P, Chen K, Pournin S et al (1995). Aggressive behavior and altered amounts of brain serotonin and norepinephrine in mice lacking MAOA. Science 268: 1763-1766.

Chen L, He M, Sibille E, Thompson A, Sarnyai Z, Baker H et al (1999). Adaptive changes in postsynaptic dopamine receptors despite unaltered dopamine dynamics in mice lacking monoamine oxidase B. J Neurochem 73: 647-655.

Chen K, Holschneider DP, Wu W, Rebrin I, Shih JC (2004). A spontaneous point mutation produces monoamine oxidase $A / B$ knock-out mice with greatly elevated monoamines and anxietylike behavior. J Biol Chem 279: 39645-39652.

Commissaris RL, Humrich J, Johns J, Geere DG, Fontana DJ (1995). The effects of selective and non-selective monoamine oxidase (MAO) inhibitors on conflict behavior in the rat. Behav Pharmacol 6: 195-202.

Dalley JW, Mar AC, Economidou D, Robbins TW (2008). Neurobehavioral mechanisms of impulsivity: fronto-striatal systems and functional neurochemistry. Pharmacol Biochem Behav 90: 250-260.

Dawson GR, Tricklebank MD (1995). Use of the elevated plus maze in the search for novel anxiolytic agents. Trends Pharmacol Sci 16: $33-36$.

De Angelis L, Furlan C (2000). The anxiolytic-like properties of two selective MAOIs, moclobemide and selegiline, in a standard and an enhanced light/dark aversion test. Pharmacol Biochem Behav 65: 649-653.

Dellu F, Contarino A, Simon H, Koob GF, Gold LH (2000). Genetic differences in response to novelty and spatial memory using a two-trial recognition task in mice. Neurobiol Learn Mem 73: 31-48.

Dourish CT, Boulton AA (1981). The effects of acute and chronic administration of beta-phenylethylamine on food intake and body weight in rats. Prog Neuropsychopharmacol 5: 411-414.

Evenden JL, Ryan CN (1996). The pharmacology of impulsive behaviour in rats: the effects of drugs on response choice with varying delays of reinforcement. Psychopharmacology (Berl) 128: 161-170.

Fisher A, Biggs CS, Eradiri O, Starr MS (2000). Dual effects of L3,4-dihydroxyphenylalanine on aromatic L-amino acid decarboxylase, dopamine release and motor stimulation in the reserpine-treated rat: evidence that behaviour is dopamine independent. Neuroscience 95: 97-111.

Fornai F, Chen K, Giorgi FS, Gesi M, Alessandri MG, Shih JC (1999). Striatal dopamine metabolism in monoamine oxidase B-deficient mice: a brain dialysis study. J Neurochem 73: 2434-2440.

Fowler CJ, von Knorring L, Oreland L (1980a). Platelet monoamine oxidase activity in sensation seekers. Psychiatry Res 3: 273-279.

Fowler CJ, Wiberg A, Oreland L, Marcusson J, Winblad B (1980b). The effect of age on the activity and molecular properties of human brain monoamine oxidase. J Neural Transm 49: 1-20.

Franklin KBJ, Paxinos G (1997). The mouse brain in stereotaxic coordinates. Academic Press: San Diego, CA.

Garrick NA, Murphy DL (1980). Species differences in the deamination of dopamine and other substrates for monoamine oxidase in brain. Psychopharmacology (Berl) 72: 27-33.

Genn RF, Tucci SA, Thomas A, Edwards JE, File SE (2003). Ageassociated sex differences in response to food deprivation in two animal tests of anxiety. Neurosci Biobehav Rev 27: 155-161.

Goad DL, Davis CM, Liem P, Fuselier CC, McCormack JR, Olsen KM (1991). The use of selegiline in Alzheimer's patients with behavior problems. J Clin Psychiatry 52: 342-345.
Grimsby J, Toth M, Chen K, Kumazawa T, Klaidman L, Adams JD et al (1997). Increased stress response and beta-phenylethylamine in MAOB-deficient mice. Nat Genet 17: 206-210.

Gundersen BB, Blendy JA (2009). Effects of the histone deacetylase inhibitor sodium butyrate in models of depression and anxiety. Neuropharmacology 57: 67-74.

Gyertyan I (1995). Analysis of the marble burying response: marbles serve to measure digging rather than evoke burying. Behav Pharmacol 6: 24-31.

Hirano K, Kimura R, Sugimoto Y, Yamada J, Uchida S, Kato Y et al (2005). Relationship between brain serotonin transporter binding, plasma concentration and behavioural effect of selective serotonin reuptake inhibitors. Br J Pharmacol 144: 695-702.

Hirschfeld-Becker DR, Biederman J, Calltharp S, Rosenbaum ED, Faraone SV, Rosenbaum JF (2003). Behavioral inhibition and disinhibition as hypothesized precursors to psychopathology: implications for pediatric bipolar disorder. Biol Psychiatry 53: 985-999.

Hranilovic D, Cicin-Sain L, Bordukalo-Niksic T, Jernej B (2005). Rats with constitutionally upregulated/downregulated platelet 5HT transporter: differences in anxiety-related behavior. Behav Brain Res 165: 271-277.

Iacono WG, Malone SM, McGue M (2003). Substance use disorders, externalizing psychopathology, and P300 eventrelated potential amplitude. Int J Psychophysiol 48: 147-178.

Jentsch JD, Taylor JR (1999). Impulsivity resulting from frontostriatal dysfunction in drug abuse: implications for the control of behavior by reward-related stimuli. Psychopharmacology (Berl) 146: 373-390.

Johansson AK, Hansen S (2000). Increased alcohol intake and behavioral disinhibition in rats with ventral striatal neuron loss. Physiol Behav 70: 453-463.

Kalaria RN, Mitchell MJ, Harik SI (1988). Monoamine oxidases of the human brain and liver. Brain 111: 1441-1451.

Kalueff AV, Tuohimaa P (2004). Grooming analysis algorithm for neurobehavioural stress research. Brain Res Brain Res Protoc 13: 151-158.

Kim JJ, Shih JC, Chen K, Chen L, Bao S, Maren S et al (1997). Selective enhancement of emotional, but not motor, learning in monoamine oxidase A-deficient mice. Proc Natl Acad Sci USA 94: 5929-5933.

Korte SM, De Kloet ER, Buwalda B, Bouman SD, Bohus B (1996). Antisense to the glucocorticoid receptor in hippocampal dentate gyrus reduces immobility in forced swim test. Eur J Pharmacol 301: 19-25.

Kubovcakova L, Krizanova O, Kvetnansky R (2004). Identification of the aromatic L-amino acid decarboxylase gene expression in various mice tissues and its modulation by immobilization stress in stellate ganglia. Neuroscience 126: 375-380.

Kuroki T, Tsutsumi T, Hirano M, Matsumoto T, Tatebayashi Y, Nishiyama $\mathrm{K}$ et al (1990). Behavioral sensitization to betaphenylethylamine (PEA): enduring modifications of specific dopaminergic neuron systems in the rat. Psychopharmacology (Berl) 102: 5-10.

Lapin IP (1990). Beta-phenylethylamine (PEA): an endogenous anxiogen? Three series of experimental data. Biol Psychiatry 28: 997-1003.

Lapin IP (1993). Anxiogenic effect of phenylethylamine and amphetamine in the elevated plus-maze in mice and its attenuation by ethanol. Pharmacol Biochem Behav 44: 241-243.

Lee M, Chen K, Shih JC, Hiroi N (2004). MAO-B knockout mice exhibit deficient habituation of locomotor activity but normal nicotine intake. Genes Brain Behav 3: 216-227.

Lenders JW, Eisenhofer G, Abeling NG, Berger W, Murphy DL, Konings CH et al (1996). Specific genetic deficiencies of the A and $\mathrm{B}$ isoenzymes of monoamine oxidase are characterized by distinct neurochemical and clinical phenotypes. J Clin Invest 97: 1010-1019. 
Leyton M, Boileau I, Benkelfat C, Diksic M, Baker G, Dagher A (2002). Amphetamine-induced increases in extracellular dopamine, drug wanting, and novelty seeking: a PET/[11C] raclopride study in healthy men. Neuropsychopharmacology 27: 1027-1035.

Lindemann L, Hoener MC (2005). A renaissance in trace amines inspired by a novel GPCR family. Trends Pharmacol Sci 26: 274-281.

Lindemann L, Meyer CA, Jeanneau K, Bradaia A, Ozmen L, Bluethmann $\mathrm{H}$ et al (2008). Trace amine-associated receptor 1 modulates dopaminergic activity. J Pharmacol Exp Ther 324: 948-956.

Llewellyn DJ (2008). The psychology of risk taking: toward the integration of psychometric and neuropsychological paradigms. Am J Psychol 121: 363-376.

Louvart H, Maccari S, Darnaudery M (2005). Prenatal stress affects behavioral reactivity to an intense stress in adult female rats. Brain Res 1031: 67-73.

Löw K, Crestani F, Keist R, Benke D, Brünig I, Benson JA et al (2000). Molecular and neuronal substrate for the selective attenuation of anxiety. Science 290: 131-134.

Mantegazza P, Riva P (1963). Amphetamine-like activity of $\beta$-phenylethylamine after a monoamine oxidase inhibitor in vivo. J Pharm Pharmacol 15: 472-478.

Megens AA, Niemegeers CJ, Awouters FH (1992). Behavioral disinhibition and depression in amphetaminized rats: a comparison of risperidone, ocaperidone and haloperidol. J Pharmacol Exp Ther 260: 160-167.

Mendlewicz J, Youdim MB (1980). Antidepressant potentiation of 5-hydroxytryptophan by L-deprenil in affective illness. $J$ Affect Disord 2: 137-146.

Moja EA, Stoff DM, Gillin JC, Wyatt RJ (1976). Dose-response effects of beta-phenylethylamine on stereotyped behavior in pargyline-pretreated rats. Biol Psychiatry 11: 731-742.

Nicolas LB, Kolb Y, Prinssen EP (2006). A combined marble burying-locomotor activity test in mice: a practical screening test with sensitivity to different classes of anxiolytics and antidepressants. Eur J Pharmacol 547: 106-115.

Njung'e K, Handley SL (1991). Evaluation of marble-burying behavior as a model of anxiety. Pharmacol Biochem Behav 38: 63-67.

Nowakowska E, Kus K, Chodera A, Rybakowski J (2001). Investigating potential anxiolytic, antidepressant and memory enhancing activity of deprenyl. J Physiol Pharmacol 52(4 Part 2): 863-873.

Oreland L (1993). Monoamine oxidase in neuropsychiatric disorders. In: Yasuhara H, Parvez S, Sandler M, Oguchi K, Nagatsu T (eds). Monoamine oxidase: basic and clinical aspects. VSP press: Utrecht, The Netherlands. pp 219-247.

Oreland L, Gottfries CG (1986). Brain and brain monoamine oxidase in aging and in dementia of Alzheimer's type. Prog Neuropsychopharmacol Biol Psychiatry 10: 533-540.

Oreland L, Hallman J (1995). The correlation between platelet MAO activity and personality: short review of findings and a discussion on possible mechanisms. Prog Brain Res 106: 77-84.

Oreland L, Nilsson K, Damberg M, Hallman J (2007). Monoamine oxidases: activities, genotypes and the shaping of behaviour. J Neural Transm 114: 817-822.

Oxenstierna G, Edman G, Iselius L, Oreland L, Ross SB, Sedvall G (1986). Concentrations of monoamine metabolites in the cerebrospinal fluid of twins and unrelated individuals - a genetic study. J Psychiatr Res 20: 19-29.

Paaver M, Nordquist N, Parik J, Harro M, Oreland L, Harro J (2007). Platelet MAO activity and the 5-HTT gene promoter polymorphism are associated with impulsivity and cognitive style in visual information processing. Psychopharmacology (Berl) 194: 545-554.
Parks CL, Robinson PS, Sibille E, Shenk T, Toth M (1998). Increased anxiety of mice lacking the serotonin1A receptor. Proc Natl Acad Sci USA 95: 10734-10739.

Pattij T, Janssen MC, Vanderschuren LJ, Schoffelmeer AN, van Gaalen MM (2007). Involvement of dopamine D1 and D2 receptors in the nucleus accumbens core and shell in inhibitory response control. Psychopharmacology (Berl) 191: 587-598.

Pellow S, Chopin P, File SE, Briley M (1985). Validation of open:closed arm entries in an elevated plus-maze as a measure of anxiety in the rat. $J$ Neurosci Methods 14: 149-167.

Picazo O, Chuc-Meza E, Anaya-Martinez V, Jimenez I, Aceves J, Garcia-Ramirez M (2009). 6-Hydroxydopamine lesion in thalamic reticular nucleus reduces anxiety behaviour in the rat. Behav Brain Res 197: 317-322.

Popova NK, Gilinsky MA, Amstislavskaya TG, Morosova EA, Seif I, De Maeyer E (2001). Regional serotonin metabolism in the brain of transgenic mice lacking monoamine oxidase A. J Neurosci Res 66: $423-427$.

Quitkin FM, Liebowitz MR, Stewart JW, McGrath PJ, Harrison W, Rabkin JG et al (1984). 1-Deprenyl in atypical depressives. Arch Gen Psychiatry 41: 777-781.

Reist C, Haier RJ, DeMet E, Chicz-DeMet A (1990). Platelet MAO activity in personality disorders and normal controls. Psychiatry Res 33: 221-227.

Rieu I, Powers SJ (2009). Real-time quantitative RT-PCR: design, calculations, and statistics. Plant Cell 21: 1031-1033.

Robinet PM, Rowlett JK, Bardo MT (1998). Individual differences in novelty-induced activity and the rewarding effects of novelty and amphetamine in rats. Behav Processes 44: 1-9.

Robinson DS, Gilmor ML, Yang Y, Moonsammy G, Azzaro AJ, Oren DA et al (2007). Treatment effects of selegiline transdermal system on symptoms of major depressive disorder: a metaanalysis of short-term, placebo-controlled, efficacy trials. Psychopharmacol Bull 40: 15-28.

Rodgers RJ, Lee C, Shepherd JK (1992). Effects of diazepam on behavioural and antinociceptive responses to the elevated plusmaze in male mice depend upon treatment regimen and prior maze experience. Psychopharmacology (Berl) 106: 102-110.

Rubino T, Vigano' D, Realini N, Guidali C, Braida D, Capurro V et al (2008). Chronic delta 9-tetrahydrocannabinol during adolescence provokes sex-dependent changes in the emotional profile in adult rats: behavioral and biochemical correlates. Neuropsychopharmacology 33: 2760-2771.

Ruchkin VV, Koposov RA, af Klinteberg B, Oreland L, Grigorenko EL (2005). Platelet MAO-B, personality, and psychopathology. J Abnorm Psychol 114: 477-482.

Sabelli H, Fahrer R, Medina RD, Ortiz Fragola E (1994). Phenylethylamine relieves depression after selective MAO-B inhibition. J Neuropsychiatry Clin Neurosci 6: 203.

Sabelli HC, Javaid JI (1995). Phenylethylamine modulation of affect: therapeutic and diagnostic implications. J Neuropsychiatry Clin Neurosci 7: 6-14.

Saura J, Bleuel Z, Ulrich J, Mendelowitsch A, Chen K, Shih JC et al (1996). Molecular neuroanatomy of human monoamine oxidases $A$ and $B$ revealed by quantitative enzyme radioautography and in situ hybridization histochemistry. Neuroscience 70: 755-774.

Scott AL, Bortolato M, Chen K, Shih JC (2008). Novel monoamine oxidase A knock out mice with human-like spontaneous mutation. Neuroreport 19: 739-743.

Shabanov PD, Lebedev AA, Meshcherov ShK, Strel'tsov VF (2005). The effects of neurochemical lesioning of dopaminergic terminals in early ontogenesis on behavior in adult rats. Neurosci Behav Physiol 35: 535-544.

Shih JC, Chen K, Ridd MJ (1999a). Monoamine oxidase: from genes to behavior. Annu Rev Neurosci 22: 197-217.

Shih JC, Ridd MJ, Chen K, Meehan WP, Kung MP, Seif I et al (1999b). Ketanserin and tetrabenazine abolish aggression in mice lacking monoamine oxidase A. Brain Res 835: 104-112. 
Skondras M, Markianos M, Botsis A, Bistolaki E, Christodoulou G (2004). Platelet monoamine oxidase activity and psychometric correlates in male violent offenders imprisoned for homicide or other violent acts. Eur Arch Psychiatry Clin Neurosci 254: 380-386.

Sostek AJ, Sostek AM, Murphy DL, Martin EB, Born WS (1981). Cord blood amine oxidase activities relate to arousal and motor functioning in human newborns. Life Sci 28: 2561-2568.

Sotnikova TD, Budygin EA, Jones SR, Dykstra LA, Caron MG, Gainetdinov RR (2004). Dopamine transporter-dependent and independent actions of trace amine beta-phenylethylamine. J Neurochem 91: 362-373.

Sotnikova TD, Caron MG, Gainetdinov RR (2009). Trace amine associated receptors (TAARs) as emerging therapeutic targets. Mol Pharmacol 76: 229-235.

Strekalova T, Spanagel R, Bartsch D, Henn FA, Gass P (2004). Stress-induced anhedonia in mice is associated with deficits in forced swimming and exploration. Neuropsychopharmacology 29: 2007-2017.

Takahashi LK, Kalin NH, Vanden Burgt JA, Sherman JE (1989). Corticotropin-releasing factor modulates defensive-withdrawal and exploratory behavior in rats. Behav Neurosci 103: 648-654.

Tarantino LM, Bucan M (2000). Dissection of behavior and psychiatric disorders using the mouse as a model. Hum $\mathrm{Mol}$ Genet 9: 953-965.

Tariot PN, Cohen RM, Sunderland T, Newhouse PA, Yount D, Mellow AM et al (1987). L-deprenyl in Alzheimer's disease. Preliminary evidence for behavioral change with monoamine oxidase B inhibition. Arch Gen Psychiatry 44: 427-433.

Thomas A, Burant A, Bui N, Graham D, Yuva-Paylor LA, Paylor R (2009). Marble burying reflects a repetitive and perseverative behavior more than novelty-induced anxiety. Psychopharmacology 204: 361-373.

Tolbert SR, Fuller MA (1996). Selegiline in treatment of behavioral and cognitive symptoms of Alzheimer disease. Ann Pharmacother 30: 1122-1129.

Trullas R, Skolnick P (1993). Differences in fear motivated behaviors among inbred mouse strains. Psychopharmacology (Berl) 111: 323-331.
Tonkiss J, Galler JR (1999). Influence of prenatal protein malnutrition on behavioral reactivity to stress in adult rats. Stress 3: 71-83.

Tschenett A, Singewald N, Carli M, Balducci C, Salchner P, Vezzani A et al (2003). Reduced anxiety and improved stress coping ability in mice lacking NPY-Y2 receptors. Eur J Neurosci 18: $143-148$.

van Gaalen MM, Brueggeman RJ, Bronius PF, Schoffelmeer AN, Vanderschuren LJ (2006). Behavioral disinhibition requires dopamine receptor activation. Psychopharmacology (Berl) 187: 73-85.

von Knorring L, Oreland L, Winblad B (1984). Personality traits related to monoamine oxidase activity in platelets. Psychiatry Res 12: 11-26.

Wall PM, Messier C (2000). Ethological confirmatory factor analysis of anxiety-like behaviour in the murine elevated plusmaze. Behav Brain Res 114: 199-212.

Whitaker-Azmitia PM, Zhang X, Clarke C (1994). Effects of gestational exposure to monoamine oxidase inhibitors in rats: preliminary behavioral and neurochemical studies. Neuropsychopharmacology 11: 125-132.

Williamson S, Gossop M, Powis B, Griffiths P, Fountain J, Strang J (1997). Adverse effects of stimulant drugs in a community sample of drug users. Drug Alcohol Depend 44: 87-94.

Winstanley CA, Theobald DE, Dalley JW, Cardinal RN, Robbins TW (2006). Double dissociation between serotonergic and dopaminergic modulation of medial prefrontal and orbitofrontal cortex during a test of impulsive choice. Cereb Cortex 16: $106-114$.

Wolinsky TD, Swanson CJ, Smith KE, Zhong H, Borowsky B, Seeman $\mathrm{P}$ et al (2007). The Trace Amine 1 receptor knockout mouse: an animal model with relevance to schizophrenia. Genes Brain Behav 6: 628-639.

Xie Z, Miller GM (2009). Trace amine-associated receptor 1 as a monoaminergic modulator in brain. Biochem Pharmacol (in press).

Zucchi R, Chiellini G, Scanlan TS, Grandy DK (2006). Trace amine-associated receptors and their ligands. $\mathrm{Br} J$ Pharmacol 149: 967-978. 